IRA-International Journal of Management \& Social Sciences

ISSN 2455-2267; Vol.06, Issue 02 (2017)

Pg. no. 292-297

Institute of Research Advances

https://research-advances.org/index.php/RAJMSS

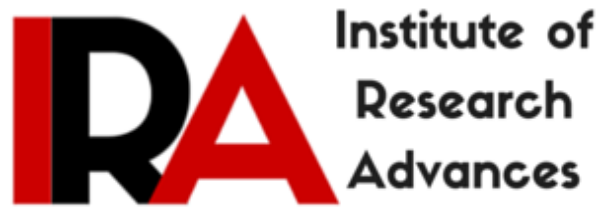

\title{
International Financial Reporting Standards Implementation in India: Benefits and Problems
}

\author{
Sruthiya $\mathbf{V} \mathbf{N}^{1}$ and Akhin $\mathbf{P}^{2}$ \\ ${ }^{1}$ St. Joseph's College (Autonomous) Devagiri,Calicut, India. \\ ${ }^{2}$ St. Joseph's College (Autonomous) Devagiri,Calicut, India.
}

Type of Review: Peer Reviewed.

DOI: http://dx.doi.org/10.21013/jmss.v6.n2.p13

How to cite this paper:

V N, Sruthiya. (2017). International Financial Reporting Standards Implementation in India: Benefits and Problems. IRA-International Journal of Management \& Social Sciences (ISSN 24552267), 6(2), 292-297. doi:http://dx.doi.org/10.21013/jmss.v6.n2.p13

(C) Institute of Research Advances

(cc) EY-NC

This work is licensed under a Creative Commons Attribution-Non Commercial 4.0 International License subject to proper citation to the publication source of the work.

Disclaimer: The scholarly papers as reviewed and published by the Institute of Research Advances (IRA) are the views and opinions of their respective authors and are not the views or opinions of the IRA. The IRA disclaims of any harm or loss caused due to the published content to any party. 


\begin{abstract}
International Financial Reporting Standard (IFRS) introduced by the International Accounting Standards Board (IASB is international financial reporting standard. IFRS is a single set of high quality, understandable and enforceable global accounting standards. It is a "principles based" set of standards which are drafted lucidly and are easy to understand and apply. IFRSs were adopted first time in 2005 by EU (European Union) and are now accepted or required in more than 120 countries. In India, this is in an implementation stage. This paper tries to study the implementation problems in India and make suggestions to solve the problems. The important implementation problems are cost, lack of awareness about IFRS among investors, and no uniformity in accounting guidance issued by various regulators (SEBI, IRDA, RBI) in India. The suggestions are to provide proper training and education to accounting professionals and employees about IFRS; Government has to reform the taxation system to match with IFRS.
\end{abstract}

Keywords: IFRS, IASB, Accounting Standards

\title{
INTRODUCTION
}

International Financial Reporting Standard (IFRS), introduced by the International Accounting Standards Board (IASB), is a single set of high quality, understandable and enforceable global accounting standards. It is a "principles based" set of standards which are drafted lucidly and are easy to understand and apply.

The International Accounting Standards Board (IASB) is an independent, private-sector body that develops and approves International Financial Reporting Standards (IFRSs). The IASB operates under the oversight of the IFRS Foundation. The IASB was formed in 2001 to replace the International Accounting Standards Committee

The International Accounting Standards Committee (IASC) was formed in 1973 through an agreement made by professional accountancy bodies from Australia, Canada, France, Germany, Japan, Mexico, the Netherlands, the United Kingdom and Ireland, and the United States of America. Additional sponsoring members were added in subsequent years. In 1982 the sponsoring "members" of the IASC comprised all of the professional accountancy bodies that were members of the International Federation of Accountants (IFAC).

From its formation in 1973 until a comprehensive reorganization in 2000, the structure for setting International Accounting Standards was known as the International Accounting Standards Committee (IASC).

As of the beginning of 2005, the global corporate financial reporting landscape has been

International Financial Reporting Standards comprising:

- International Financial Reporting Standards (IFRS) - standards issued after 2001

- International Accounting Standards (IAS) - standards issued before 2001

- Interpretations originated from the International Financial Reporting Interpretations

- Committee (IFRIC) -issued after 2001

- Standing Interpretations Committee (SIC) - issued before 2001.

\section{STATEMENT OF THE PROBLEM}

IFRSs were adopted first time in 2005 by the European Union (EU). IFRSs are now accepted or required in more than 120 countries. It is in an implementation stage in India. IFRS implementation affects several areas of a business entity .Mainly implementation problems and cost. India is going to implement the 
IFRS in a phased manner. It has a lot of benefits to different stakeholders like companies, accounting professionals, investors and regulators. But firms will face different implementation problems in the future. So this paper tries to study the challenges and benefits of IFRS implementation in India and also try to identify some solutions to the issues so identified.

\section{OBJECTIVES OF THE STUDY}

1. To study the preparedness of Indian firms in implementing the IFRS

2. To identify the implementation issues, if any, faced by firms in India

\section{SOURCES OF DATA}

The study has been conducted mainly on the basis of secondary data, literature review and personal interviews with experts. Journals, research papers, web resources and newspaper articles were used for gathering relevant data.

\section{LITERATURE REVIEW}

Many studies have been conducted on IFRS. Some of the relevant studies in this context are summarized below to gain a theoretical perspective on IFRS implementation.

Dr.Pran Krishansing Boolaky studied problems and challenges to the private and public sector enterprises in his paper 'IFRS in small island economies'. Using data from Mauritius the IFRS conversion and implementation process is investigated with focus on implementation problems. The implementation problems are expressed in terms of difficulties related to the IFRSs. The paper reports that though IFRS conversion was smooth in Mauritius, and the conversion cost was significant.

In another study, Abhiruchi Aswal ,Gaurav Agarwal and Subhajit Das examined the impact of IFRS on Indian companies. In their view, IFRS is going to have significant impact on the Indian corporate, largely due to the significant difference in the Indian GAAP and IFRS.

Pawan Jain tried to analyze the information available on IFRS adoption process in India in his paper IFRS implementation in India, opportunities and challenges .It also discusses the IFRS adoption procedure in India and the utility for India in adopting IFRS. The paper discusses the problems faced by the stakeholders (Regulators, Accountants, Firms etc.) in the process of adoption of IFRS in India.

In a sample of 102 non-European Union countries, Karthik Ramanna and Ewa Sletten studied variations in the decision to adopt International Financial Reporting Standards (IFRS). There is evidence that more powerful countries are less likely to adopt IFRS, consistent with more powerful countries being less willing to surrender standard-setting authority to an international body.

Francois Aubert and Gary Grudnitski had reported the results of conducting a two-stage analysis on the impact and importance of mandatory adoption of International Accounting Reporting Standards on European Union (EU) firms in their paper, 'The impact and importance of mandatory adoption of IFRS in India'.

\section{IFRS in India}

The financial reporting standards currently followed in India are a combination of the standards notified by the Ministry of Corporate Affairs, guidance issued by the Securities Exchange Board of India (SEBI), guidance from the Institute of Chartered Accountants of India (ICAI), and industry-specific guidance from regulators. 
In 2007 India announced that it would fully adopt IFRS by 2011 which is to be done in phases. First phase was to include the companies which were part of NSE Nifty, BSE Sensex, the companies which had shares or other securities listed on stock exchanges outside India and the companies (whether listed or not) which had a net worth in excess of Rs 10 billion. The companies covered in this phase were required to prepare an Opening Balance Sheet in accordance with IFRS converged standards as of April 01, 2011 and would follow the IFRS converged standards from this date. The second phase was to cover the Firms (listed or not) with a net worth in excess of Rs 5 billion but less than Rs 10 billion. These firms would prepare an opening Balance Sheet in accordance with IFRS converged standards as of April 01, 2013 and would follow IFRS converged standards from this date. Rest of the firms were to follow the process from April 01, 2014. But this announcement of Ministry of Corporate Affairs was not implemented.

After the enactment of the Companies Act, 2013, The Ministry of Corporate Affairs has now shifted its focus on rolling out international reporting standards for Indian companies which were to be implemented beginning April 1, 2011. According to the draft plan, the ministry wants to implement the international financial reporting standards (IFRS) beginning with companies that have a net worth of over Rs 10 billion from April 1, 2015. In the second phase, both listed and unlisted companies with a net worth of over Rs 5 billion but less than Rs 10 billion will have to converge with the international accounting standards from the financial year beginning April 1, 2016.

\section{BENEFITS OF IFRS}

Conversion to IFRS offers companies a number of important benefits.

1. For Raising Capital from Overseas. Most of the companies are raising capital from overseas which requires all information in International standard understandable to them. Uniform accounting standard is very essential for this.

2. It also expects an increase in mergers and acquisitions opportunities since the major challenge of conversion of financial statements to a uniform standard (US GAAP) would be removed because of IFRS.

3. Comparison and benchmarking of financial data with international competitors would be possible through IFRS implementation.

4. Another major benefit of IFRS is that the management of a company can view all the companies in a group on a common platform. This will reduce the time and efforts involved to adjust the accounts in order to comply with the requirements of the national GAAP (Generally Accepted Accounting Principle)

5. The firms will have less complexity in accounting

6. IFRS will increase transparency in accounting

7. It will facilitate cross border investment leading to accelerated economic growth

8. IFRS adoption will improve the quality of financial information

\section{PROBLEMS OF IFRS IMPLEMENTATION IN INDIA}

Indian companies will have to face a number of challenges and issues in implementing IFRS. IFRS is going to have significant impact on the Indian firms largely due to the significant difference in the Indian GAAP and IFRS.

1. Fair value instead of historical cost. The most important and most talked about is that under IFRS, balance sheet items would have to be fair valued compared to the current practice of carrying it at historical cost. This will certainly complicate the situation for companies which are in huge debt. Not only would they have to show increased debt positions which would impact their credit rating but also impact their financial ratios. 
2. Cost of implementation. Implementation of IFRS requires incurring large expenditure like IFRS software cost, training cost for employees, advisory fee, audit fee etc. A new system always considers value of money, so that it becomes mandatory for companies to find out cost-benefit analysis.

3. Lack of Awareness. Due to lack of awareness about different IFR standards, investors face difficulties in comparing, analyzing and taking appropriate decisions. IFRS mainly focuses on presenting financial statement and focus is low on the users of accounting standard.

4. Necessity of new software package. Development of new software package is essential for successful implementation of IFRS.

5. Lack of Technical Knowledge. As the accounting professionals are too familiar with the Indian GAAP, they may find it difficult to work with IFRS.

6. No uniformity in accounting guidance issued by different regulators. Reserve Bank of India issues guidance for banking companies, the Insurance Regulatory and Development Authority issues guidance for insurance companies, the Central Electricity Regulatory Commission issues guidance for electricity companies, SEBI issues guidance for listed companies, and the Ministry of Corporate Affairs too issues certain guidance.

\section{SUGGESTIONS}

Following are some of the suggestions to manage the problems of IFRS implementation in India

1. Proper education and training to accounting professionals and employees about IFRS

2. Educate the investors and shareholders about the IFRS

3. Different regulators in India (RBI, SEBI, IRDA etc.) have to constitute committees to study the proper implementation of IFRS

4. Develop user friendly software with minimum cost.

5. Government has to reform the taxation system to match with IFRS.

\section{CONCLUSION}

International Financial Reporting Standard introduced by the International Accounting Standards Board (IASB) is intended at improving transparency and addresses some of the objectivity concerns in accounting. The major issue in implementation is lack of knowledge regarding its convergence with the IndAS.

\section{REFERENCES}

1. PranKrishansing, IFRS in Small Island Economies: Problems and challenges to the private and public-sector enterprises: Using data from Mauritius( Electronic copy available at: http://ssrn.com/abstract=1578075) (2010)

2. Abhiruchi Kant Aswal ,GauravAgarwal\&Subhajit Das, (Electronic Copy available at ASa1gaurav.files.wordpress.com)

3. Pawan Jain IFRS Implementation in India: Opportunities and Challenges (2011)

4. World Journal of Social Sciences Vol. 1. No. 1. Pp.125 - 136, March 2011 
5. KartikRamanna\&EwaSletten, Why do Countries Adopt International Financial Reporting Standards(http://ssrn.com/abstract=1460763 (2009)

6. François Aubert\&Gary Grudnitski, The Impact and Importance of Mandatory Adoption Of International Financial Reporting Standards in Europe (Electronic Copy available at Electronic copy available at: http://ssrn.com/abstract=1276338)

\section{OTHER REFERENCES}

1. B. Kapoor and JyotiRuhela IFRS IMPLEMENTATION "ISSUES AND CHALLENGES FOR INDIAVSRD International Journal of Business and Management Research, Vol. 3 No. 2 February 2013

2. S.P. Srivastava \& Sanjay Kumar Patel, CONVERGENCE OF INDIAN ACCOUNTING STANDARDS WITH IFRS : PROSPECTS AND CHALLENGES , SMS Varanasi Vol. V, No. 2; December, 2009

3. Vandana Saxena Poria, IFRS IMPLEMENTATION AND CHALLENGES IN INDIA Published in MEDC Monthly Economic Digest - August 2009 issue

4. Sumon Bhattacharjee, Problems of Adoption and Application of International Financial Reporting Standards (IFRS) in Bangladesh International Journal of Business Management Vol 4 No 12 ,Dec 2009

5. Ray Ball International Financial Reporting Standards (IFRS): Pros and Cons for Investors (2006) (Electronic Copy available at SSRN: http://ssrn.com/abstract=929561)

6. Holger Daske ,Luzi Hail, Christian Leuz and Rodrigo S. Verdi Mandatory, : IFRS Reporting Around the World: Early Evidence on the Economic Consequences(2008) (Electronic Copy available at SSRNhttp://dx.doi.org/10.2139/ssrn.1024240)

7. Naomi N Soderstorm \& Kevin Jilain Sun IFRS adoption and accounting Quality A review (2007) Eletronic copy available at http://ssrn.com/abstract=1008416)

8. Robert W Mcgee and Galina Prebragenskaya Problems of Implementing International Accounting Standards in a Transition Economy: A Case Study of Russia (2003) http://ssrn.com/abstract=459363.

9. Huifa Chen, Qingliang Tang, Yihong Jiang and Zhijun Lin, The Role of International Financial Reporting Standards in Accounting Quality: Evidence from the European Union, Journal of International Financial Management \& Accounting, Vol. 21, No. 3, Autumn 2010

10. Anne B. Fosbre, Ellen M. Kraft and Paul B. Fosbre, The Globalization of Accounting Standards: IFRS vs. US GAAP Global. Journal of Business Research, Vol. 3, No. 1, pp. 61-71, 2009

\section{Webiliography:}

ifrsapplication@ifrs.org.

www.ifrs.com

www.icai.com 